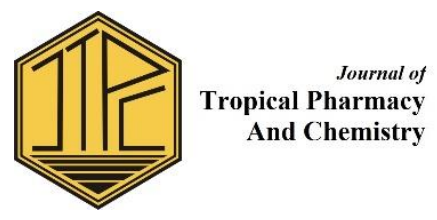

\title{
Aphrodisiac Activity of Ethanol Extract of Cratoxylum sumatranum (Jack) Blume Stems on Isolated Rat Corpus cavernosum
}

\author{
Sjarif Ismail ${ }^{1,2}$, Meiliati Aminyoto ${ }^{3}$ \\ ${ }^{1}$ Research Center on Drugs and Public Health Mulawarman University, Indonesia \\ ${ }^{2}$ Pharmacology Laboratory, Faculty of Medicine Mulawarman University, Indonesia \\ ${ }^{3}$ Public Health Laboratory, Faculty of Medicine Mulawarman University, Samarinda \\ *Corresponding author email: ismail@fk.unmul.ac.id and ismail8997@yahoo.com
}

\begin{abstract}
Cratoxylum sumatranum (Jack) Blume of the Hypericaceae family is known as "Bentaleng" by Dayak Benuaq. In ethnobotany, Cratoxylum sumatranum stems (CSS) is used as energy drink or aphrodisiac, but its effect has not been scientifically proven. The objective of this research was to evaluate the aphrodisiac activity of CSS extract by screening the aphrodisiac activity in vitro. CSS was collected from Kutai Kertanegara Regency, East Kalimantan Province. Extraction was by maceration with ethanol solvent for three days. Remaceration was done twice. In vitro screening of aphrodisiac activity used isolated rat corpus cavernosum. The organ was placed into a $10 \mathrm{~mL}$ chamber containing $\mathrm{Krebs}$-Henselheit solution at $\mathrm{pH} 7.4,37^{\circ} \mathrm{C}$ and aerated with carbogen gas. After acclimation, a contraction test was performed with phenylephrine solution and after reaching the peak of contraction at plateau the Control (solvent extract) or CSS ethanol extract was administered at cumulatively increased concentration. Vasodilation activity was known if the contraction response was decreased after the extract's administration and expressed in percent contraction with negative value. The result of this study showed that CSS ethanol extract induce vasodilatory response on rat Corpus cavernosum blood vessels. Vasodilation activity was increasing with increasing concentration of extract given compared to Control. This study concluded that CSS ethanol extract has aphrodisiac activity and it act directly through the vasodilatation of blood vessels in the rat corpus cavernosum.
\end{abstract}

Keywords: Cratoxylum sumatranum, aphrodisiac, in vitro, corpus cavernosum, vasodilation

Submitted on: 3 January 2018

Accepted on: 16 July 2018

DOI: https://doi.org/10.25026/jtpc.v4i3.150

\section{INTRODUCTION}

Erectile dysfunction (ED) is a sexual dysfunction disorder on men due to the inability to achieve and maintain an erection of the penis for a satisfactory sexual relationship [1]. Prevalence of ED 
in the world is estimated at about $2 \%$ in adult men $<40$ years old and reaches $86 \%$ in older men $>80$ years [2]. There are many options to deal with ED, phosphodiesteration inhibitor under the name sildenafil is most widely used but its raw materials are still imported and the price is expensive so the national pharmaceutical industry is difficult to develop. The global drug market for erectile dysfunction through 2020 is promising because it will reach a market size of 4 billion dollars and sildenafil (Viagra ${ }^{\circledR}$ ) dominates the market by $47 \%$ in 2014 [3,4]. Research for invention of new drug's raw material to overcome ED is urgently needed for the sake of national pharmaceutical needs in order to compete and enlarge its market share.

A potential plant to be studied is Cratoxylum sumatranum (Jack) Blume ( $C$. sumatranum) from the Hypericaceae family, which is a wild plant and in abundance in East Kalimantan secondary forest around Suharto Hill, Kutai Kertanegara Regency. Their other name are C. clandestinum Blume, $C$. floribundum (Turcz.) Fern. Vill., $C$. hornschuchii Blume, $C$. hypericinum Merr., C. racemosum Blume [5]. Its local name are Haremeng and $\mathrm{Ki}$ remeng (Sundanese); Arong, Klampet, Lampet, Marong, Urang-urangan (Javanese); Bentaleng (Ethnic Dayak Benuaq, East Kalimantan). Medicinal plants Cratoxylum sp. ethnobotanically are used to treat abdominal pain (bark), burns (leaves), scabies and ulcers (exudat), fever (leaves and stems) [6]. From ethnobotanic search in East Kalimantan, $C$. sumatranum stems were used to increase male virility or aphrodisiac [7], but this effect has not been scientifically proven. The aim of this research was to study the aphrodisiac activity of $C$. sumatranum stem extract by screening for its aphrodisiac activity in vitro.

\section{EXPERIMENTAL SECTION}

\section{Chemicals and Materials}

Ethanol, Calcium chloride, Glucose, Magnesium chloride, Potassium chloride, Potassium dihydrogen phosphate, Sodium chloride, Sodium bicarbonate, Potasium chloride, and DMSO from Merck; Phenylephrine (PE) and Methacholine (META) from SigmaAldrich. All other reagents used in the study were of analytical grade.

\section{Animal}

Young male Wistar rats (4-6 month old) weighing 200-250 g were obtained from the Animal House Unit, Faculty of Medicine, Mulawarman University. The animal had free access to food and drinking water, and were kept at room temperature of $25 \pm 1{ }^{\circ} \mathrm{C}$. Study protocol was reviewed and approved by the institutional ethics committee of Faculty of Medicine Mulawarman University before the start of the work.

\section{Plant material and extraction}

C. sumatranum stems was picked from Soeharto Hill, Kutai Kertanegara Reagency of East Kalimantan Province and authenticated by the taxonomist of Foresty Faculty of Mulawarman University. Specimen samples were stored at Pharmacology Laboratory, Faculty of Medicine Mulawarman University repository with specimen number CS01/XI/2016. The stems were washed, cut in small pieces and dried in an oven at $60^{\circ} \mathrm{C}$, then ground into powder. Extraction was by maceration using ethanol solvent with a ratio of 1:4 for three days. Remaceration was done twice. The extract was dried in a vacuum evaporator at $50^{\circ} \mathrm{C}$ until a constant yield of $17.1 \%$ on repeated weighing was obtained. 
Aphrodisiac Activity of Ethanol Extract of Cratoxylum sumatranum (Jack) Blume Stems on Isolated Rat Corpus cavernosum

\section{Effects of CSS ethanol extract on corpus cavernosum}

Six male albino rats were used in this experiment. The animals were anesthetized with Ketamine $(100 \mathrm{mg} / \mathrm{kg})$. The rat's isolated corpus cavernosum was prepared according to the method described by Keegan et al. (1999) and Paskaloglu et al. (2004) [8,9]. The penises were removed and the corpus cavernosa was carrefully dissected in a dish containing chilled KrebsHenselheit solution at $\mathrm{pH} 7.4$ and aerated with carbogen gas $\left(95 \% \mathrm{O}_{2}+5 \% \mathrm{CO}_{2}\right)$. Each corpus cavernosum yielded a single strip of $2 \times 2 \times 15 \mathrm{~mm}$. Strips of rat corpus cavernosum placed in a $10 \mathrm{~mL}$ organ chamber. Tissue baths containing KrebsHenselheit solution at $\mathrm{pH} 7.4$ and $37^{\circ} \mathrm{C}$, aerated with carbogen gas. The rat corpus cavernosum strips were connected to isometric force-displacement transducers (model 7003, Ugo Basile), and changes in the tension were recorded continuously by using an octal bridge amplifier and Power Lab/16 SP digital recorder (AD Instrument). Data acquisition and processing were carried out with Chart v.5 software (AD Instrument). Tissues were preloaded with 1 $\mathrm{g}$ of tension and allowed to equilibrate for $90 \mathrm{~min}$ in Krebs-Henselheit solution that was changed at $15 \mathrm{~min}$ interval. Each strip was submaximally contracted with PE $\left(10^{-5}\right.$ M). After the contractile response due to PE has stabilized, relaxation responses to the different treatment were assessed as a percentage of the PE-induced contractile responses $=(($ submaximal contraction with PE only - contraction in the presence of extract) / submaximal contraction with $\mathrm{PE}$ only) x 100.

\section{Data analysis}

The results obtained were expressed as mean \pm standard error of mean (SEM), data were analyzed statistically using student's $t$-test at significance level of $p<0.05$.

\section{Result and Discussion}

The addition of PE $\left(10^{-5} \mathrm{M}\right)$ to the strip of rat corpus cavernosum produced contraction responses. The extracts solvent containing DMSO-ethanol 10\% was used as Controls. On the other hand, the $C$. sumatranum stems extract elicited a concentration-dependent vasodilation responses on the PE-precontracted rat corpus cavernosum (Fig 1). As the concentration of the extract put into the chamber increased, the vasodilation activity of the corpus cavernosum was also increased.

The test results of the effects of Control and $C$. sumatranum ethanol extract on strip of rat corpus cavernosum can be seen in the Figure 1. The extract solvent could induce percent contraction with a small negative value. Increasing concentration of the solvent that were put into the chamber containing strip of rat corpus cavernosum could cause percent contraction with increasing negative value and at Control concentration which was equivalent to extract concentration of 3 $\mathrm{mg} / \mathrm{ml}$, a $(-1,82 \pm 0.53) \%$ response was obtained. This indicated that the extract solvent could cause mild vasodilation on blood vessels in the corpus cavernosum.

C. sumatranum stems ethanol extracts could cause percent contraction with a mild negative value. Increasing concentration of extracts administered into the chamber containing the strip of rat corpus cavernosum could cause percent contraction with an increasingly negative value and at extract's concentration of 3 $\mathrm{mg} / \mathrm{ml}$ a response of $(-7.85 \pm 0.66) \%$ was obtained. This indicated that the extract of C. sumatranum stems could cause vasodilation on blood vessels in the corpus cavernosum.

The result of statistical test by $t$ test with $\mathrm{p}>0.05$ at concentrations of 0.03 , 0.1 , and $0.3 \mathrm{mg} / \mathrm{ml}$ showed no significant difference between the control group and 
Aphrodisiac Activity of Ethanol Extract of Cratoxylum sumatranum (Jack) Blume Stems on Isolated Rat Corpus cavernosum

the $C$. sumatranum stems extract group at the same concentration. The result of statistical test by $t$-test with $\mathrm{p}<0.05$ at concentration of 1 and $3 \mathrm{mg} / \mathrm{ml}$ showed significant different result between the control group and the $C$. sumatranum stems extract group at the same concentration.

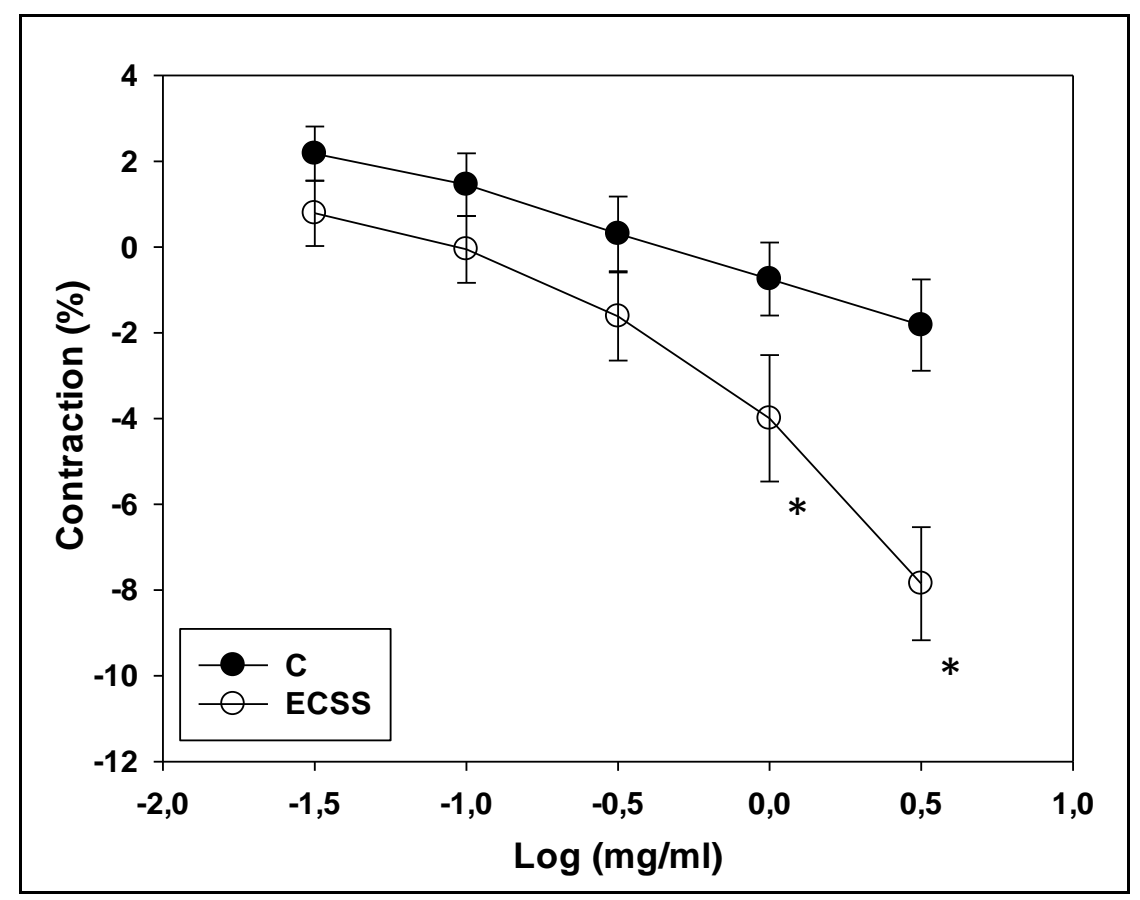

Figure 1: Concentration dose curve of CSS extract effect compared to control on an isolated corpus cavernosum

Description: $n=5$ rats. Data is expressed in mean \pm SEM. Negative results indicates vasodilation response. $\mathrm{C}=$ Control (DMSO-ethanol 10\%). ECSS $=$ extract of Cratoxylum sumatranum stems. * $t$-test was significantly different with $p<0.05$ if percent contraction in corpus cavernosum was compared with control at same concentration.

Erection on penis occurs due to the helicin arterioles vasodilatation in the corpus cavernosum such that the arterial blood flows faster to fill the lacunar spaces on the corpus cavernosum causing the penis to become tense. When the helicin arterioles in the corpus cavernosum contracts, it causes the arterial blood flow into the lacunar space to be inhibited and so the penis becomes flaccid. The balance between factors affecting vasodilation or vasoconstriction in the lacunar cavities and arteriole smooth muscles in the corpus cavernosum will determine if the penis will be in an erect or flaccid state [10]. Nitric oxide (NO) plays an important role in the erection response, it was released from the vascular endotehelium or from the nonadrenergic non-cholinergic neurons (NANC) from the central or peripheral nervous system [11,12]. Nitric oxide synthase (NOS) is an enzyme that converts L-arginine to $\mathrm{NO}$ and Lcitrulline. NOS is present in the endothelium (eNOS), neuronal tissue (nNOS), and epithelial tissue within the pelvic and urogenital structures of males 
Aphrodisiac Activity of Ethanol Extract of Cratoxylum sumatranum (Jack) Blume Stems on Isolated Rat Corpus cavernosum

$[13,14]$. eNOS activation by an agonist in the vascular endothelium will produce NO which can diffuse easily into the blood vessels' smooth muscle in the corpus cavernosum. NO activates soluble guanylate cyclases (sGS) such as those present in the blood vessels which induce guanosine triphosphate (GTP) conversion to cyclic guanosine monophosphate (cGMP). cGMP stimulates calcium ions out from the blood vessels smooth muscle in the corpus cavernosum, resulting in blood vessels vasodilation that causes penis erection.

NO can also be released if there is sexual stimulation or the influence of drugs. Decreased calcium ions in the blood vessels' smooth muscle in the corpus cavernosum can also be caused by inhibition of the phosphodiesterase (PDE) enzyme. This enzyme converts cyclic adenosine monophosphate (cAMP) and cGMP to AMP or GMP. Inhibition of PDE enzyme will cause cGMP levels to remain high such that the blood vessels in the corpus cavernosum remain in a state of relaxation that results in more blood coming into the corpus cavernosum and the penis will remain erect or tense [15].

This study was still in its early stages to scientifically prove the local ethnic knowledge of local aphrodisiacs. In this study CSS extracts was proved to be aphrodisiacs with direct action mechanisms of causing blood vessels vasodilation in the corpus cavernosum. It is necessary to further investigate the action mechanism of blood vessels' vasodilation in the Corpus cavernosum on CSS extract's intervention whether it is affected by NO or directly activate sGC and inhibit PDE by administration of NO antagonists or methylene blue as sGC antagonists or PDE antagonists.

\section{CONCLUSION}

The ethanol extract of $C$. sumatranum stems was proven in vitro to have an aphrodisiac effect as it could induce vasodilation in the isolated rats corpus cavernosum.

\section{ACKNOWLEDGMENT}

The research is entirely funded by the Year 2016 Lecturer Research Grant from Mulawarman University.

\section{REFERENCES}

[1] NIH Concensus Development Panel on Impotence. 1993. Impotence. Journal of the American Medical Association, 270:83-90.

[2] Prins J, Blanker MH, Bohnen AM, Thomas S, \& Bosch JLHR. 2002. Prevalence erectile dysfunction: a systematic review of populationbased studies. International Journal of Impotence Research, 14:422-432.

[3] Technavio. 2016. Global erection dysfunction market 2016-2020. SKU: IRTNTR9506, Inviniti Research Limited. Available at: https://www.technavio.com/report/gl obal-health-and-wellness-globalerectile-dysfunction-market-20162020. Acessed 10/23/2017.

[4] Grand View Research. 2017. Erectile dysfunction drug market worth $\$ 3.2$ billion by 2022 . Grand View Research Inc. Available at: http://www.grandviewresearch.com/ press-release/global-erectiledysfunction-drugs-market. Acessed 10/23/2017.

[5] The Plant List. 2017. Cratoxylum sumatranum (Jack) Blume. The plant list: a working list of all plant species. Available at: http://www.theplantlist.org/tpl1.1/re cord/kew-2742440. $\quad$ Acessed 10/23/2017. 
Aphrodisiac Activity of Ethanol Extract of Cratoxylum sumatranum (Jack) Blume Stems on Isolated Rat Corpus cavernosum

[6] Heyne K. 1987. Tumbuhan berguna Indonesia. Diterjemahkan oleh Badan Litbang Kehutanan Jakarta. Penerbit: Koperasi Karyawan Departemen Kehutanan. Page 13711373.

[7] Badan Penelitian dan Pengembangan Kalimantan Timur. 2006. Identifikasi dan pengembangan fitokimia tanaman obat unggulan Kaltim. Bidang Ekonomi dan Pembangunan Badan Penelitian dan Pengembangan Provinsi Kaltim. Laporan Penelitian.

[8] Keegan A, Cotter MA, \& Cameron NE. 1999. Effects of chelator treatment on aorta and corpus cavernosum from diabetic rats. Free Radical Biology and Medicine Journal, 27(5-6):536-43.

[9] Paskaloglu K, Sener G, \& Ayanğolu-Dülger G. 2004. Melatonin treatment protects against diabetes-induced functional and biochemical changes in rat aorta and corpus cavernosum. European Journal of Pharmacology, 499(3):345-54.

[10] Anderson KE. 2011. Mechanisms of penile erection and basis for pharmacological treatment of erectile dysfunction. Pharmacological Review, 63:811859.
[11] Lue TF. 2000. Erectile dysfunction. The New England Journal of Medicine, 342(24)1802-1813.

[12] Burnett AL. 2006. The role of nitric oxide in erectile dysfunction: implications for medical therapy. Journal of Clinical Hypertension, 8(12):53-62.

[13] Burnett AL, Ricker DD, Chamness SL, Maguire MP, Crone JK, Bredt DS, Snyder SH, \& Chang TS. 1995. Localization of nitric oxide synthase in the reproductive organs of the male rat. Biology of Reproduction, 52(1):1-7.

[14] Gonzalez CM, Brannigan RE, Bervig T, Zelner D, Podlasek CA, McKenna KE, \& McVary KT. 2001. Protein and gene expression of nitric oxide synthase isoforms I and III in the rat penile shaft. Journal of Andrology, 22(1):54-61, 2001.

[15] Cartledge JS, Minhas I, Eardley, \& Morrison JF. 2000. Endothelial and neuronal derived nitric oxide mediated relaxation of corpus cavemosal smooth muscle in a new rat, in vitro model of erectile function. International Journal of Impotence Research, 12:213-221. 